\title{
Field efficacy of genetically modified FK 95 Bollgard Il cotton for control of bollworms, Lepidoptera, in Ghana
}

\author{
Mumuni Abudulai* ${ }^{\mathbb{D}}$, Emmanuel Boachie Chamba, Jerry Asalma Nboyine, Ramson Adombilla, Iddrisu Yahaya,
} Ahmed Seidu and Foster Kangben

\begin{abstract}
Background: Cotton (Gossypium hirsutum L.) cultivation in Ghana is constrained by bollworms that damage squares (flower buds) and developing bolls, resulting in loss in seed cotton yield. Control of these insects is heavily dependent on insecticides that are costly and also pose health and environmental risks to users. Potential alternative control strategies have focused on using cotton genetically modified with the soil-borne bacterium Bacillus thuringiensis Berliner (Bt) that confer resistance against these pests. This study evaluated the field efficacy of the genetically modified FK 95 Bollgard II (FK 95 BG II) cotton for control of bollworms in Ghana.

Results: Results showed that bollworm densities in the FK 95 BG II cotton were lower compared with those in the FK 37 conventional cotton. However, populations of the natural enemies, ladybird beetles Coccinella undecimpunctata $\mathrm{L}$ and lacewings Chrysoperla carnea [Stephens] were higher in the Bt compared with the conventional technology of pest management. On average, seed cotton yields were higher in the FK 95 BG II compared to those in the FK 37. Net profit and cost-benefit ratios also were higher for the Bt technology compared with the conventional practice, indicating that farmers would benefit more if they adopt the $B t$ technology of cotton pest management.

Conclusion: The Bt cotton technology of pest management was more effective and economical than the conventional practice of wholly relying on insecticides and was a better management option for bollworm in cotton in the savanna ecology of Ghana.
\end{abstract}

Keywords: Cotton, Gossypium hirsutum L, Bollworms, Yield loss, Insecticide control, Genetically modified, Bacillus thuringiensis (Bt)

\section{Background}

Cotton (Gossypium hirsutum L.) is an important and a major cash crop in northern Ghana, where it is widely cultivated because of its adaptability to the climatic conditions of the area. It serves as a source of lint for the textile and garment industries in Ghana. Moreover, besides serving as a source of income and employment to farmers and their families, its export earns foreign exchange for the country. However, in spite of the high potential for its cultivation in Ghana, seed cotton yields on farmers' fields remain low averaging $500 \mathrm{~kg} \mathrm{ha}{ }^{-1}$ compared to about

*Correspondence: mabudulai@yahoo.com

CSIR-Savanna Agricultural Research Institute, P. O. Box 52, Tamale, Ghana
$2000 \mathrm{~kg} \mathrm{ha}^{-1}$ in other cotton-producing countries [1, 2]. The low productivity is attributed to several factors, key among them is the problem of insect pests, particularly bollworms. A substantial part of the cotton production budget is allocated to controlling insect pests [3].

The crop is attacked in the field by numerous insect pests, with the bollworm complex being the most important in Ghana [2, 3]. This complex comprises the American bollworm, Helicoverpa armigera (Hubner) (Noctuidae); spiny bollworm, Earias spp. (Nolidae); pink bollworm, Pectinophora gossypiella Saunders (Gelechiidae); Sudan bollworm, Diparopsis watersii (Rothschild) (Noctuidae); and the false codling moth, Thaumatotibia (=Cryptophlebia) leucotreta Meyrick (Tortricidae) [2, 3]. 
The larval stages of these insects damage plant terminals and also chew into squares (flower buds) and developing bolls, resulting in abscission of these floral parts and loss in seed cotton yield. Complete yield loss due to these insects can occur in unprotected or poorly protected fields [4].

Conventional breeding for resistance against these pests has not yielded the desired results. Consequently, they are managed mainly with insecticides in Ghana and many other cotton-growing areas in West Africa [2-4]. Globally, cotton is responsible for about $16-25 \%$ of all chemical insecticides used in agriculture, which is more than what is used for any other single crop [6, 7 , 10]. Although most of these insecticides are effective for control, they pose health hazards to farmers who use them and also contaminate the environment. Moreover, they are expensive and their indiscriminate use can cause emergence of resistant biotypes in insect populations resulting in control failures such as those reported for pyrethroid insecticide use in parts of West Africa [5, 8, 9]. In an effort to scale down on insecticide use, amidst fears for environmental contamination and insect resistance build-up, genetic modification of plants for resistance to insect pests has been found to be a better and environmentally friendlier alternative [10]. Genetic modification with the soil-borne bacterium Bacillus thuringiensis (Bt) Berliner has been used to control insect pests in several crops [11-13]. Genetically modified cotton contains the $B t$ gene(s) that produce(s) toxins or bio-pesticides inside the plant to offer protection against insects. It has specific activity against lepidopteran insects such as the bollworm complex due to specific receptors and conditions in the caterpillar's gut that allow activation of the $B t$ crystal proteins $[14,15]$. The objective of the present study was to evaluate the field efficacy of the genetically modified Bollgard II (BG II) cotton, FK 95 BG II for control of cotton bollworms in Ghana.

\section{Materials and methods}

Description of the experimental area

Field studies were conducted on-station at the research farm of the Council for Scientific and Industrial
Research-Savanna Agricultural Research Institute (CSIR-SARI) in Nyankpala $\left(9^{\circ} 42^{\prime} \mathrm{N}, 0^{\circ} 92^{\prime} \mathrm{W}\right)$ and onfarm on farmers' fields at five different locations $\left(9^{\circ} 23^{\prime} \mathrm{N}\right.$, $0^{\circ} 07^{\prime} \mathrm{W}-10^{\circ} 50^{\prime} \mathrm{N}, 1^{\circ} 58^{\prime} \mathrm{W}$ ) in northern Ghana. The experimental area is located in the Guinea Savanna zone which is characterized by grassland vegetation interspersed with few trees. Soils of the experimental fields were generally of sandy loam texture with a $\mathrm{pH}$ of 4.5-5.5 and organic matter content of $0.89-0.99 \%$. Rainfall of the area is unimodal and falls from May to October followed by a long dry period from November to April. The annual rainfall ranges from $900 \mathrm{~mm}$ to $1200 \mathrm{~mm}$ and temperature from 21 to $40^{\circ} \mathrm{C}$.

\section{Planting material and land preparation}

Seeds of the FK 95 BG II cotton which carries the genes coding for Cry1Ac and Cry2Ab, and the FK 37 conventional cotton were obtained from Monsanto, South Africa and Burkina Faso, respectively. Seeds of the two cotton varieties were planted simultaneously in comparative studies. The land was tractor-ploughed and levelled manually with the hand hoe before planting.

\section{Experimental design and treatments}

The on-station experiment consisted of four treatments (Table 1) arranged in a randomized complete block design (RCBD) with four replications. Each treatment plot had eight (8) rows $10 \mathrm{~m}$ long with inter- and intra-row spacing of $0.75 \mathrm{~m}$ and $0.40 \mathrm{~m}$, respectively. Blocks and plots were separated by $5-\mathrm{m}$ unplanted alleys to minimize insecticide drift to unsprayed plots. The experimental area was surrounded by a $12-\mathrm{m}$ border of conventional cotton that served as refugia for dilution of resistance genes to the $B t$ toxins [16]. The standard practice of six insecticide sprays were made at 2-week intervals beginning at 35 days after planting (DAP) [17] in designated plots that were sprayed for both bollworms and sucking insects (Table 1). The conventional cotton refugia also were protected according to the standard practice of six sprays. The insecticides Tihan (spirotetramat $75 \mathrm{~g} / \mathrm{l}+$ flubendiamide $100 \mathrm{~g} / \mathrm{l}$ ) (BCS-Crop Protection, Accra, Ghana) were applied for the first three sprays followed by Thunder (imidacloprid

Table 1 Cotton treatment and descriptions of insecticide application

\begin{tabular}{lll}
\hline No. & Cotton treatment $^{\text {a }}$ & Treatment descriptions \\
\hline 1 & SFK 95 BG II & Bollgard II (BG II) cotton sprayed for bollworm and also for all other insects \\
2 & SOFK 95 BG II & Bollgard II cotton unsprayed for bollworm but sprayed for all other insects \\
3 & SFK 37 (near-isogenic version) & Conventional cotton sprayed for bollworm and also for all other insects \\
4 & SOFK 37 (near-isogenic version) & Conventional cotton unsprayed for bollworm but sprayed for all other insects \\
\hline
\end{tabular}

FK 95 BG II is genetically modified Bollgard II (BG II) cotton, while the FK 37 is the non-modified conventional cotton

a $\mathrm{S}$ and $\mathrm{SO}$ attached to cotton variety denote sprayed and unsprayed, respectively 
$100 \mathrm{~g} / \mathrm{l}+$ betacyfluthrin $45 \mathrm{~g} / \mathrm{l}$ ) (BCS-Crop Protection, Accra, Ghana) for the last three sprays. The application rate was $0.035 \mathrm{~kg}$ a.i.ha ${ }^{-1}$ for Tihan and $0.029 \mathrm{~kg}$ a.i. ha ${ }^{-1}$ for Thunder. For plots that were sprayed for only sucking insects mainly cotton stainers, only two applications were made with Tihan alternated with Thunder at 2-week interval at boll opening at 90 DAP. The compound fertilizer NPK (23-10-5) was used for basal application at 2 weeks after planting at the rate of $250 \mathrm{~kg} \mathrm{ha}^{-1}$, while sulphate of ammonia was applied as top dress at 5 weeks after planting at the rate of $125 \mathrm{~kg} \mathrm{ha}^{-1}$. Pendimethalin pre-emergence herbicide (Stomp 440 Herbicide, BASF Corp., Victoria, Australia) was applied within 2 days after planting at $1.0 \mathrm{~kg}$ a.i. ha ${ }^{-1}$. This was followed by hand weeding of fields at 2 and 4 weeks after planting.

The on-farm experiment consisted of two treatments, FK 95 BG II and FK 37 conventional cotton, arranged in a RCBD and replicated at five sites. At each site, the two treatments were planted adjacent to each other, each on a 0.25 ha plot. A spacing of $5-\mathrm{m}$ fallow was maintained between and around plots and a 12-m border of conventional cotton surrounded the trial as refugia. The FK 37 conventional cotton was protected against insects according to the standard practice of six sprays from 35 DAP as described earlier in the on-station experiment. For the FK 95 BG II cotton, only two sprays were made and targeted against sucking insects as described earlier. All the agronomic practices were carried out as detailed for the on-station experiment.

\section{Data collection and analysis}

In the on-station experiment, bollworm infestation and damage to squares and bolls were assessed on 6 randomly selected plants from the 6 inner rows of each plot. Counts were taken weekly from first square to cut-out. To develop data package on the impact of $B t$ cotton on nontarget organisms (NTOs) such as pollinators and predators, counts were also made at the same time of these insects/ arthropods on each of the 6 plants that were assessed for bollworms in each plot. Due to logistic constraints, weekly sampling of insects was not carried out in the on-farm experiment.

At maturity, seed cotton yield in the on-station experiment was determined from the harvests from the 6 inner rows of plots less $2 \mathrm{~m}$ on both ends of the rows to reduce border effects. In the on-farm experiment, the entire plot was harvested and seed cotton yield recorded. Yield loss due to bollworms was calculated using the formula:

$$
\% \text { Yield loss }=\frac{\mathrm{TB}-\mathrm{UB}}{\mathrm{TB}} \times 100,
$$

where TB is the total number of bolls on plants and UB is the number of undamaged bolls.

The data from the two experiments were subjected to analysis of variance separately using the SAS statistical package [18]. Count data were subjected to square-root transformation before analysis. Means were separated using Fischer's protected LSD test at $P<0.05$.

\section{Partial budget analysis}

Partial budget analysis was used to assess the cost-benefit ratio of treatments. The cost-benefit ratio was calculated from the seed cotton yield of each treatment and the cost of insecticide treatments. It was used to assess the economic viability of the $B t$ technology compared to the conventional practice of managing bollworms in cotton. Government-approved price for seed cotton was used to determine the value of yield of $B t$ cotton over that of conventional control, while market prices of insecticides and insecticide spray charges were used to compute variable cost of production. These calculations were based on the assumption that the market price of $B t$ seed cotton was equivalent to that of conventional seed cotton. The benefit or gross margin over control was calculated using the formula below:

$$
\begin{aligned}
\text { Gross margin over control } & =\text { value of yield over control } \\
& =P_{\text {market }} \times\left(Q_{b t}-Q_{\text {control }}\right),
\end{aligned}
$$

where $P_{\text {market }}$ is the market price of seed cotton/kilogram, $Q_{\mathrm{bt}}$ is the yield of $B t$ seed cotton $(\mathrm{kg} / \mathrm{ha})$, and $Q_{\text {con- }}$ trol is the yield of the conventional cotton control $(\mathrm{kg} / \mathrm{ha})$.

The cost-benefit ratio was calculated using the following:

$$
\text { cost-Benefit Ratio }=\frac{\text { Value of yield over control }(\mathrm{Gh} \pitchfork / \mathrm{ha})}{\text { Total cost of insecticide protection }(\mathrm{Gh} \Phi / \mathrm{ha})}
$$

\section{Results and discussion}

\section{Effect on bollworm population densities}

Bollworm population densities were lowest on the FK 95 BG II cotton sprayed for both sucking insects and bollworms or for sucking insects only and highest on the FK 37 conventional cotton sprayed for sucking insects only (Table 2). Bollworm densities in FK 95 BG II sprayed for sucking insects only were similar to those in FK 37 given insecticide protection for both sucking insect and bollworms. Averaged across spraying regimes for each cotton variety, bollworm densities were 0.06 larvae/plant for FK 95 BG II compared with 0.50 larvae/plant for FK 37 conventional cotton. The low densities of bollworms in the $B t$ cotton compared with the conventional cotton are consistent with reports that $B t$ cotton is effective for control of cotton bollworms $[1,19]$. 
Table 2 Effect of treatments on bollworm densities, seed cotton yield and yield loss

\begin{tabular}{llll}
\hline Treatment & Bollworms/plant & Yield (kg/ha) & Yield loss (\%) \\
\hline SFK 95 BG II & $0.013 \mathrm{c}$ & $1657.7 \mathrm{a}$ & $13.64 \mathrm{c}$ \\
S0FK95 BG II & $0.10 \mathrm{bc}$ & $1173.0 \mathrm{~b}$ & $20.91 \mathrm{bc}$ \\
SFK 37 & $0.18 \mathrm{~b}$ & $1149.7 \mathrm{~b}$ & $31.67 \mathrm{~b}$ \\
SOFK37 & $0.71 \mathrm{a}$ & $509.4 \mathrm{c}$ & $59.55 \mathrm{a}$ \\
Pr $>$ F & 0.0004 & $<0.0001$ & $<0.0001$ \\
CV (\%) & 6.40 & 14.52 & 21.61 \\
\hline
\end{tabular}

Column means accompanied by different letters are significantly different at $P<0.05$

SFK 95 BG II = Bollgard II cotton sprayed for both sucking insect pests and bollworm; SOFK95 BG II= Bollgard II cotton sprayed for only sucking insect pests but unsprayed for bollworm; SFK $37=$ conventional cotton sprayed for both sucking insect pests and bollworms; SOFK $37=$ conventional cotton sprayed for only sucking insect pest but unsprayed for bollworm

\section{Effect on natural enemies of insects}

The different treatments in the on-station experiment significantly affected the abundance of the natural enemies, ladybird beetles Coccinella undecimpunctata $\mathrm{L}$ and lacewings Chrysoperla carnea [Stephens] (Table 3). Generally, populations of these natural enemies were higher on both FK 95 BG II and FK 37 conventional plots that were sprayed twice for sucking insects compared with those that were sprayed six times for both sucking insects and bollworms. However, spiders (e.g. Cheiracanthium mildei $\mathrm{L}$. Koch) populations were not significantly different $(P>0.05)$ among the treatments.

Several workers have found no adverse effects on nontarget natural enemies resulting from direct toxicity of $B t$ crops in the field [20-23]. Thus, the reduced populations of ladybird beetles and lacewings observed in plots that received multiple insecticide sprays could be attributed to the effect of the insecticides. Li et al. [20] observed that whereas conventionally grown cotton requires more

Table 3 Effect of treatments on mean number of natural enemies per plant

\begin{tabular}{lllc}
\hline Treatment & Ladybird beetle & Spider & Lacewing \\
\hline SFK 95 BG II & $0.16 \mathrm{c}$ & $0.14 \mathrm{a}$ & $0.08 \mathrm{c}$ \\
S0FK95 BG II & $0.31 \mathrm{~b}$ & $0.31 \mathrm{a}$ & $0.25 \mathrm{a}$ \\
SFK 37 & $0.23 \mathrm{bc}$ & $0.20 \mathrm{a}$ & $0.10 \mathrm{~b}$ \\
SOFK 37 & $0.53 \mathrm{a}$ & $0.21 \mathrm{a}$ & $0.25 \mathrm{a}$ \\
Pr>F & $<0.0001$ & 0.4935 & $<0.0001$ \\
CV (\%) & 7.35 & 8.43 & 3.21
\end{tabular}

Column means accompanied by different letters are significantly different at $P<0.05$

SFK 95 BG II = Bollgard II cotton sprayed for both sucking insect pests and bollworm; SOFK95 BG II=Bollgard II cotton sprayed for only sucking insect pests but unsprayed for bollworms; SFK $37=$ conventional cotton sprayed for both sucking insect pests and bollworms; SOFK $37=$ conventional cotton sprayed for only sucking insect pest but unsprayed for bollworms insecticide treatments for bollworm control that generally are toxic to both pests and non-target arthropods, $B t$ cotton fields often have significantly more non-target arthropods than conventionally grown cotton fields. In a separate study, however, Abudulai et al. [2] did not find any negative effect of the insecticides used in this study to natural enemies.

\section{Effect on seed cotton yield}

Seed cotton yield was significantly $(P<0.05)$ affected by cultivar and spraying regime. In the on-station experiment, the highest yield was recorded in FK 95 BG II sprayed for both sucking insects and bollworms, while the lowest yield was recorded in FK 37 conventional cotton sprayed for sucking insects only (Table 2). Yields in FK 95 BG II sprayed for sucking insects but unsprayed for bollworms were comparable to those in the FK 37 conventional cotton protected against both sucking insects and bollworms. Yields in the FK 95 BG II were more than double those of the FK 37 conventional cotton when both plots were sprayed for sucking insects only. Seed cotton yield was $1415.4 \mathrm{~kg} \mathrm{ha}^{-1}$ for the FK 95 BG II cotton compared with $829.6 \mathrm{~kg} \mathrm{ha}^{-1}$ for the FK 37 conventional cotton, when averaged across spraying regimes for each cotton variety. This represented a $41 \%$ yield increase in the FK 95 BG II $B t$ cotton over the yield in the FK 37 conventional cotton. The results from the on-farm experiment also showed that yield was significantly greater in the FK 95 BG II $B t$ cotton compared with the FK 37 conventional cotton (Fig. 1). Yield increased by $19 \%$ in the FK 95 BG II over that of the FK 37 cotton. Gouse et al. [10] reported average yield increase above $50 \%$ with $B t$ cotton compared with conventional cotton for smallholders in South Africa. The yield increases observed with the $B t$

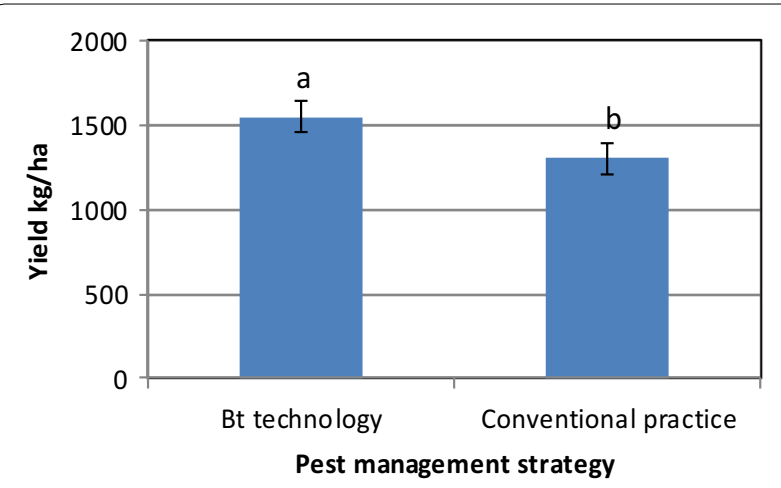

Fig. 1 Comparative efficacy (mean $\pm S E$ ) of Bt technology and conventional management practice of bollworms on seed cotton yield in northern Ghana. Plots in the Bt technology were sprayed twice for control of sucking insects only, while plots in the conventional practice were sprayed six times for control of both sucking insects and bollworms 
Table 4 Partial budget analysis for effect of Bt cotton on insecticide application frequency on cotton bollworm

\begin{tabular}{|c|c|c|c|c|c|c|c|c|c|}
\hline \multirow[t]{2}{*}{ Treatment } & \multirow{2}{*}{$\begin{array}{l}\text { Insecticide } \\
\text { supplication } \\
\text { frequency }\end{array}$} & \multicolumn{3}{|l|}{ Output } & \multicolumn{3}{|l|}{ Input } & \multirow[t]{2}{*}{ Net profit } & \multirow{2}{*}{$\begin{array}{l}\text { Cost- } \\
\text { benefit } \\
\text { ratio }\end{array}$} \\
\hline & & $\begin{array}{l}\text { Seed cotton } \\
\text { yield (kg/ha) }\end{array}$ & $\begin{array}{l}\text { Increased } \\
\text { yield } \\
\text { over control } \\
\text { (kg/ha) }\end{array}$ & $\begin{array}{l}\text { Value } \\
\text { of increased } \\
\text { yield (Ghc) }\end{array}$ & $\begin{array}{l}\text { Cost } \\
\text { of insecticide } \\
\text { (GhC) }\end{array}$ & $\begin{array}{l}\text { Labour } \\
\text { charges } \\
\text { for spraying } \\
\text { (GhC) }\end{array}$ & $\begin{array}{l}\text { Total cost } \\
\text { (Ghc) }\end{array}$ & & \\
\hline FK 95 BG ॥ & 6 & 1657.7 & 1148.3 & 987.3 & 120.0 & 300.0 & 420.0 & 567.3 & $1: 1.35$ \\
\hline FK 95 BG ॥ & 2 & 1173.0 & 663.6 & 570.7 & 32.0 & 100.0 & 132.0 & 438.7 & $1: 3.32$ \\
\hline FK 37 & 6 & 1149.7 & 640.3 & 550.4 & 120.0 & 300.0 & 420.0 & 130.4 & 1:0.31 \\
\hline FK 37 & 2 & 509.4 & - & - & - & - & & & \\
\hline
\end{tabular}

Price of seed cotton at Ghana cedis (Ghc) 0.86/kg; insecticides Tihan at Ghc120.00/litre and Thunder at Ghc70.00/litre

Both insecticides applied at $0.2 \mathrm{~L} / \mathrm{ha}$; Tihan and Thunder applied thrice each ( 6 sprays) and Thunder only ( 2 sprays)

Labour for spraying at Ghל50.00/ha

NB: Ghç4.50= US\$1.00

technology in the current study further demonstrated the superiority of the technology to the current conventional practice of wholly relying on insecticide sprays for bollworm control $[24,25]$.

As expected, yield loss was highest $(P<0.05)$ in FK 37 sprayed for sucking insects only and lowest in FK 95 BG II sprayed for both sucking insects and bollworms, which was not lower than FK 95 BG II protected against sucking insects only (Table 2). The results also showed that yield was negatively correlated $(r=-0.85170 ; P<0.0001)$ with bollworm densities, while a positive correlation was measured between bollworm densities and yield loss $(r=0.84387 ; P<0.0001)$. Similar observations were made in a previous study [2], which demonstrates further the importance of bollworms infestations in limiting seed cotton yield.

\section{Cost-benefit ratio of treatments}

The on-station results showed a higher net profit for the $B t$ technology than the conventional practice of relying wholly on insecticide protection (Table 4). The cost-benefit ratio was also higher with the $B t$ technology than the conventional practice, indicating a higher return to investment with the $B t$ technology than with the conventional practice. For example, a cost-benefit ratio of 1:3.32 for the $B t$ technology with two sprays showed that a Gh\$1.00 (US\$0.22) investment in the $B t$ technology yielded a return of Gh\$3.32 (US\$0.74) compared to the ratio of 1:0.31 for the conventional practice with six sprays which yielded a return of Gh\$0.31 (US\$0.07). Similarly, the on-farm results showed that the increased yield of $247.67 \mathrm{~kg}$ in the $B t$ over that of the conventional practice resulted in a net profit of Gh\$81.00 (US\$18.00) and a cost-benefit ratio of 1:0.60 (data not shown). These results are consistent with the report that the $B t$ cotton technology increases profits of farmers [17, 26]. Farmers would therefore benefit more in terms of increased yields and returns to their investment when they adopt the $B t$ technology to manage bollworms compared with the conventional management with insecticides. Moreover, the associated decreased cost as a result of reduced number of sprays with the $B t$ cotton has an added advantage of minimizing the risk of pesticide poisoning to farmers [27] and also can compensate for higher cost, if any of $B t$ cotton seeds.

\section{Conclusion}

The study showed that seed cotton yields on average were higher with the $B t$ cotton technology compared with the conventional practice of wholly relying on insecticide sprays for managing bollworms. The positive yield increases translated into higher net profits and cost-benefit ratio for the $B t$ cotton technology compared with the conventional practice. The findings are significant when the benefits in terms of the increased income that would accrue to farmers from the use of the $B t$ cotton technology are considered. The reduced number of insecticide sprays from six to two with the $B t$ technology also reduces the risks to farmers from insecticide exposure and poisoning.

\section{Abbreviations \\ CSIR: Council for Scientific and Industrial Research; SARI: Savanna Agricultural Research Institute; Bt: Bacillus thuringiencis; BG: Bollgard; RCBD: Randomized} complete block design; DAP: Days after planting; NTO: Non-target organisms.

\section{Authors' contributions}

$M A$ and EBC conceived and designed the study. JAN, RA, AS and FK collected the data. MA, JAN and EBC analysed the data and drafted the manuscript. $M A$, JAN, IY and EBC contributed to the critical revision of the manuscript for important intellectual content. All authors read and approved the final manuscript.

\section{Acknowledgements}

The authors acknowledge Monsanto Company for providing seeds of FK 95 Bollgard II cotton and funds for the study. The authors specially thank Fred Anaman, James Yaw Kwabena, Mohammed Hafiz Alhassan, Rebecca Kaba and Soweiba Abdulai of the Entomology Section of CSIR-SARI for technical support. 


\section{Competing interests}

The authors declare that there are no competing interests regarding the publication of this paper.

\section{Availability of data and materials}

The data sets used and/or analysed in the preparation of the manuscript can be made available to anyone who desires to see it from the corresponding author on request.

\section{Consent for publication}

Not applicable.

\section{Ethics approval and consent to participate}

Ethical approval and consent from our organization and farmer participants were sought and granted for the conduct of the study and to participate in research paper writing and submission to any relevant journal.

\section{Funding}

This research was supported through funds provided by Monsanto Company, USA.

\section{Publisher's Note}

Springer Nature remains neutral with regard to jurisdictional claims in published maps and institutional affiliations.

Received: 31 August 2018 Accepted: 24 October 2018

Published online: 03 November 2018

\section{References}

1. Hillocks RJ. Is there a role for Bt cotton in IPM for smallholders in Africa?". Int J Pest Manag. 2005;51:131-41.

2. Abudulai M, Seini SS, Nboyine J, Seidu A, Ibrahim Y Jr. Field efficacy of some insecticides for control of bollworms and impact on non-target beneficial arthropods in cotton. Expl Agric. 2017. https://doi.org/10.1017/ s0014479717000072.

3. Abudulai M, Abatania L, Salifu AB. Farmers'knowledge and perceptions of cotton insect pests and their control practices in Ghana. J Sci Technol. 2006:26:39-46.

4. Michel B, Togola M, Téréta I, Traoré NN. Cotton pest management in Mali: issues and recent progress. Cah Agric. 2000;9:109-15.

5. Martin T, Ochou OG, Hala NF, Vassal JM, Vassayre M. Pyrethroid resistance in the cotton bollworm, Helicoverpa armigera (Hübner) in West Africa. Pest Manag Sci. 2000;56:549-54.

6. EJF. The deadly chemicals in cotton. Environmental justice foundation in collaboration with pesticide action network. London, UK, ISBN No. 1-904523-10-2, 2007. https://ejfoundation.org//resources/downloads/ the_deadly_chemicals_in_cotton.pdf

7. Naranjo SE. Impacts of $B t$ transgenic cotton on integrated pest management. J Agric Food Chem. 2011;59:5842-51.

8. Vaissayre M, Martin T, Vassal JM, Silvie P. Pyrethroid resistance monitoring program for the cotton bollworm in West Africa. 2000. http://www.cnpa. embrapa.br/produtos/algodao/publicacoes/cba3/algo080.pdf. Accessed 17 Nov 2017

9. Martin T, Chandre F, Ochou OG, Vaissayre M, Fournier D. Pyrethroid resistance mechanisms in the cotton bollworm Helicoverpa armigera (Lepidoptera: Noctuidae) from West Africa. Pestic Biochem Physiol. 2002;74:17-26.

10. Gouse M, Kirsten JF, van der Walt WJ. Bt cotton and Bt maize: An evaluation of direct and indirect impact on the cotton and maize farming sectors in South Africa. Pretoria: Department of Agriculture; 2008. p. 99.
11. Chakraborty J, Sen S, Ghosh P, Sengupta A, Basu D, Das S. Homologous promoter derived constitutive and chloroplast targeted expression of synthetic cry $1 \mathrm{Ac}$ in transgenic chickpea confers resistance against Helicoverpa armigera. Plant Cell Tiss Organ Cult. 2016;125:521-35.

12. Kaur A, Sharma M, Sharma C, Kaur H, Kaur N, Sharma S, et al. Pod borer resistant transgenic pigeon pea (Cajanus cajan L.) expressing cry1Ac transgene generated through simplified Agrobacterium transformation of pricked embryo axes. Plant Cell Tiss Organ Cult. 2016;127:717-27.

13. Mabubu Jl, Nawaz M, Hua H. Advances of transgenic Bt-crops in insect pest management: an overview. J Entomol Zool Stud. 2016;4:48-52.

14. Glare TR, O'Callaghan M. Bacillus thuringiensis: biology, ecology and safety. New York: Wiley; 2000.

15. Keshavareddy G, Kumar ARV. Bacillus thuringiensis. In: Omkar O, editor. Ecofriendly pest management for food security. Elsevier: Amsterdam; 2016. p. 443-73.

16. Wu K, Feng H, Guo Y. Evaluation of maize as a refuge for management of resistance to $B t$ cotton by Helicoverpa armigera (Hubner) in the Yellow River cotton-farming region of China. Crop Prot. 2004;23:523-30.

17. Traoré H, Héma SAO, Traoré K. Bt cotton in Burkina Faso demonstrates that political will is key for biotechnology to benefit commercial agriculture in Africa. In: Wambugu F, Kamanga D, editors. Biotechnology in Africa, emergence, initiatives and future. Springer, New York, 2014. p. 291.

18. SAS Institute. SAS user's guide. 9th ed. Cary: SAS Institute; 1998.

19. Krattiger AF. Insect resistance in crops: a case study of Bacillus thuringiensis $(B t)$ and its transfer to developing countries. ISAAA Brief No. 2, International Service for the Acquisition of Agri-Biotech Applications. 1996. p. 51.

20. Li Y, Romeis J, Wang P, Peng Y, Shelton AM. A comprehensive assessment of the effects of Bt cotton on Coleomegilla maculata demonstrates no detrimental effects by Cry1Ac and Cry2Ab. PLoS ONE. 2011;6(7):e22185. https://doi.org/10.1371/journal.pone.0022185.

21. Moar WJ, Eubanks M, Freeman B, Turnipseed S, Ruberson J, Head G. Effects of Bt cotton on biological control agents in the Southeastern United States. In: Proceedings of the first international symposium on biological control of arthropods; 2002. Honolulu, USA.

22. Pehu E, Ragasa C. Agricultural biotechnology transgenics in agriculture and their implications for developing countries, Background paper for the World Development Report; 2008, Washington, D. C. The World Bank, 2007.

23. Romeis J, Meissle M, Bigler F. Transgenic crops expressing Bacillus thuringiensis toxins and biological control. Nat Biotechnol. 2006;24(1):63-71.

24. Wu K, Guo Y, Lv N, Greenplate JT, Deaton R. Efficacy of transgenic cotton containing a Cry1 Ac gene from Bacillus thuringiensis against Helicoverpa armigera (Lepidoptera: Noctuidae) in northern China. J Econ Entomol. 2003;96(4):1322-8.

25. Héma SAO, Some HN, Traoré O, Greenplate J, Abdennadher M. Efficacy of transgenic cotton plant containing the Cry1 Ac and Cry2Ab genes of Bacillus thuringiensis against Helicoverpa armigera and Syllepte derogata in cotton cultivation in Burkina Faso. Crop Prot. 2009;28:205-14.

26. Kathage J, Qaim M. Economic impacts and impact dynamics of Bt (Bacillus thuringiensis) cotton in India. PNAS. 2012;109(29):11652-6.

27. Kouser S, Qaim M. Impact of Bt cotton on pesticide poisoning in smallholder agriculture: a panel data analysis. Ecol Econ. 2011;70:2105-13.

Ready to submit your research? Choose BMC and benefit from:

- fast, convenient online submission

- thorough peer review by experienced researchers in your field

- rapid publication on acceptance

- support for research data, including large and complex data types

- gold Open Access which fosters wider collaboration and increased citations

- maximum visibility for your research: over $100 \mathrm{M}$ website views per year

At BMC, research is always in progress.

Learn more biomedcentral.com/submissions 